\title{
Pengaruh Kepuasan Kerja, Disiplin Kerja dan Etos Kerja terhadap Kinerja Karyawan PT. Keihin Indonesia
}

(Studi Kasus Pada Bagian Die Casting)

\section{Suryadi}

Program Studi Manajemen, Universitas Pelita Bangsa suryadihunga@gmail.com

\section{Karyono}

Program Studi Manajemen, Universitas Pelita Bangsa karyono.71@gmail.com
Abstract
PT. Keihin Indonesia adalah perusahaan manufaktur yang memperoduksi mesin motor dan mobil khusunya karburator produk utamanya adalah Injector seperti CV Carburetor, Piston Carburetor, Injector dan Airbag G Sensor . Penelitian ini untuk mengetahui apakah ada pengaruh kepuasan kerja, disiplin kerja dan etos kerja terhadap kinerja karyawan PT. Keihin indonesia dengan metode kuantitatif dan melalui perhitungan populasi dan sampel menggunakan rumus slovin dan menyebar kuisioner kepada karyawan dan menggunakan spss 22 untuk pengolahan data. Hasil penelitian ini dapat dilihat dengan Uji $T$ secara parsial dan menyatakan bahwa Kepuasan kerja berpengaruh positif dan signifikan terhadap kinerja, disiplin kerja berpengaruh psitif dan signifikan terhadap kinerja dan etos kerja memiliki pengaruh yang positif dan signifikan terhadap kinerja karyawan PT. Keihin Indonesia
Keywords Pengaruh kepuasan kerja, disiplin kerja dan etos kerja terhadap kinerja karyawan

\section{PENDAHULUAN}

Di era globalisasi seperti sekarang ini sumber daya manusia dalam suatu organisasi memegang peranan yang penting, sumber daya manusia sebagai salah satu tolak ukur untuk meningkatnya atau menurunnya kinerja karyawan yang pada akhirnya mempengaruhi kemajuan suatu organisasi. Dalam usahanya, kinerja dipercaya juga akan meningkatkan perhatiannya terhadap bagian-bagian sumber daya manusia, sehingga visi misi dan nilai perusahaan dapat tercapai.

Karyawan adalah sumber daya yang sangat penting dalam organisasi, tanpa adanya karyawan dalam suatu organisasi sangat sulit untuk mencapai tujuan karena karyawan yang menentukan keberhasilan atau kegagalan suatu organisasi, dengan memiliki tenaga kerja yang berbakat, dengan motivasi yang tinggi adalah salah satu sumber daya yang mahal oleh organisasi, pada dasarnya manusia merupakan 
subjek dan objek perbaikan yang merupakan faktor penting, terutama peningkatan kualitas sumber daya manusia yang menjadi prioritas utama.

Selain dari sumber daya manusia yang baik keberhasilan suatu organisasi dapat di pengaruhi juga oleh kepuasan kerja, karena pentingnya memperhatikan aspek kepuasan kerja, karyawan akan merasa hak nya terpenuhi sehingga pemberian gaji dengan tenaga yang di keluarkan dari karyawan seimbang. Hal ini mendukung ada nya sikap kerja yang penting dan harus di pertimbangkan oleh atasan apabila ingin meningkatakan kinerja karyawan nya semakin berkembang nya pemikiran manusia karena kurang merasa puas terhadap yang di capai sehingga banyak memunculkan ide ide baru sehingga perusahaan semakin berkembang.

Kepuasan Kerja adalah perilaku kerja yang dibangun dalam kesadaran yang kuat, keyakinan utama, yang digabungkan dengan kewajiban total terhadap pandangan dunia kerja pada dasarnya. Salah satu faktor yang dapat meningkatkan kinerja karyawan yaitu disiplin adalah fungsi operatif ke-6 dari manajemen sumber daya manusia kedisiplinan merupakan fungsi yang terpenting karena semakin baik disiplin karyawan, semakin tinggi prestasi kerja karyawan yang dapat di capai nya. Tanpa disiplin yang baik sulit bagi perusahaan untuk mencapai hasil yang optimal.

Kedisiplinan adalah kesadaran dan kesiapan seorang pekerja untuk patuh pada setiap standar dan norma yang ada dalam suatu organisasi. Dengan ini akan mendorong energi atau semangat untuk bekerja, dan mendukung tujuan organisasi.

Kemudian untuk meningkatkan kinerja karyawan di butuhkan etos kerja yang baik. Etos kerja yang baik seyogya nya harus di miliki setiap karyawan. karena setiap perusahaan membutuhkan kerja keras dan komitmen yang tinggi setiap karyawan, kalo tidak organisasi akan sulit berkembang dan susah masuk dalam pangsa pasar di industri, akan melibatkan karyawan untuk kinerjanya di antaranya setiap organisasi memiliki etos kerja dan etos kerja yang dimiliki oleh seseorang atau kelompok akan menjadi sumber motivasi bagi perusahaan.

Bahwa dalam diri seseorang atau kelompok dikatakan memiliki etos kerja keras yang tinggi, jika memberikan tanda-tanda seperti memiliki penilaian yang sangat baik terhadap hasil pekerjaan manusia, pekerjaan sebagai suatu hal yang sangat penting bagi kehidupan manusia, kerja dirasakan sebagai suatu gerakan yang bermakna. karena keberadaan dan pekerjaan manusia dihayati sebagai proses yang membutuhkan ketekunan dan sekaligus ide yang bagus untuk tercapainya perusahaan.

PT. Keihin Indonesia merupakan perusahaan manufaktur yang memproduksi mesin motor dan mobil khususnya karburator. Didirikan pertama kali di jepang pada tahun 1956, hingga sekarang PT. Keihin Indonesia tetap konsisten dalam mengembangkan produksi mesin motor dan mobil. Produk utama PT. Keihin Indonesia adalah Injector seperti CV Carburetor, Piston Carburetor, njector dan Airbag G Sensor.

Berdasarkan observasi yang saya lakukan terjadi nya permasalahan di PT. Keihin Indonesia yaitu, Kenaikan jabatan tidak diukur dengan skill dengan alat bantu assesment employee, hanya orang dekat dengan atasan saja yang akan dipromosikan, kurang nya komunikasi antara rekan kerja sehingga sering terjadi kesalahpahaman antara rekan kerja. Kurang nya kesadaran karyawan untuk 
menggunakan alat pelindung diri. Ketidakseriusan pada saat jam kerja. Hal ini yang menyebabkan penurunan kinerja karyawan pada PT. Keihin ndonesia.

Bedasarkan hasil observasi di atas bahwa terjadinya penurunan kinerja di PT. Keihin Indonesia di sebabkan oleh kepuasan kerja,disiplin kerja dan etos kerja yang kurang baik. Berikut data penurunan kinerja karyawan PT. Keihin ndonesia dilihat dari hasil output produksi:

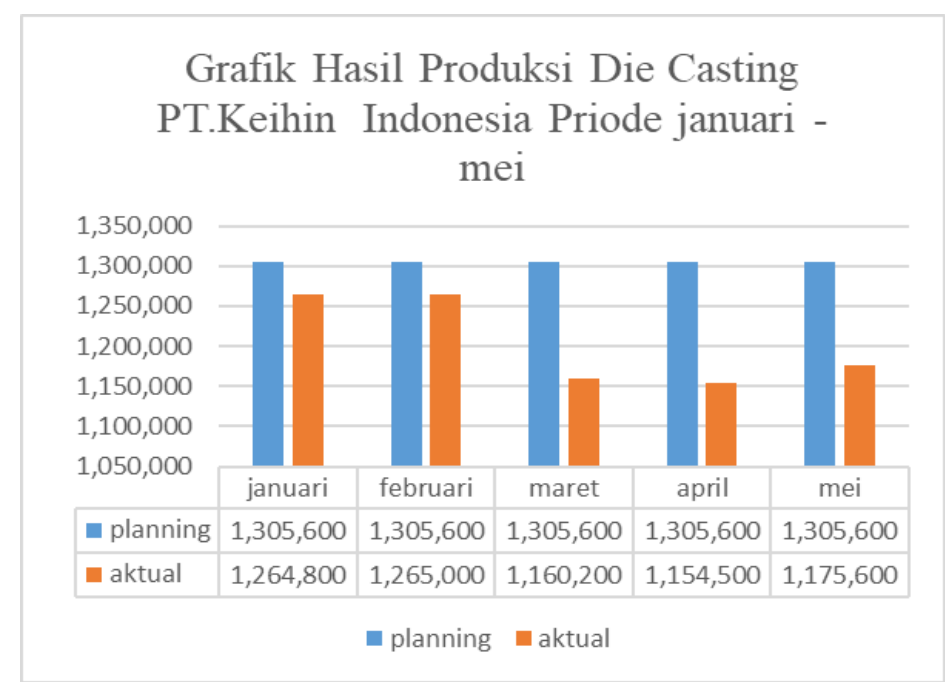

Gambar1.1 Data Hasil produksi PT. Keihin

Sumber : PT. Keihin 2021

Menurut Gambar 1.1 diatas hasil kinerja karyawan PT. Keihin pada bagian die casting belum memenuhi target dari perusahaan dan mengalami penurunan jumlah produksi pada data aktual di bulan Maret sampai Mei

Hal ini di dukung oleh Oxy Rindiantika sari yang menyatakan bahwa Kepuasan kerja berpengaruh positif dan signifikan terhadap kinerja karyawan, penelitian Mardi Astutik juga menyatakan bahwa Disiplin kerja berpengaruh positif dan signifikan terhadap kinerja karyawan, Nurjaya et.al juga menyatakan bahwa etos kerja memiliki pengaruh yang signifikan terhadap kinerja

\section{KAJIAN PUSTAKA}

\section{Kinerja}

Mangkunegara dalam Nurjaya et al., (2021) Kinerja adalah hasil pekerjaan dalam kualitas dan jumlah yang dicapai oleh seorang pekerja dalam melakukan kewajibannya sesuai dengan kewajiban yang diberikan kepadanya.

Porter dan lawren Azhari \& Supriyatin, (2020) menyatakan bahwa kinerja merupakan fungsi untuk berprestasi yang diwujudkan dengan kemampuan yang perlu melakukan tanggung jawab, sehingga dapat dibentuk suatu model kondisi hasil kinerja (keinginan menangani pekerjaan, kemampuan, mendapatkan apa dan bagaimana melakukannya). 


\section{Indikator kinerja}

Indikator kinerja menurut Robbins dalam Tjiong Fei Lie, (2018) sebagai berikut :

\section{Kualitas}

Pengukuran kualitas kinerja dilihat dari kesan perwakilan dari sifat pekerjaan yang disampaikan dan kesempurnaan tugas pada kemampuan dan kapasitas pekerja.

\section{Kuantitas}

Kuantitas yang dimaksud adalah kuantitas yang dibuat dikomunikasikan dalam kata-kata seperti jumlah unit, jumlah siklus gerakan selesai.

\section{Ketepatan Waktu}

Ketepatan waktu adalah tingkat gerakan yang diselesaikan menuju awal waktu yang dinyatakan, dilihat dari tujuan pengorganisasian dengan hasil yang menghasilkan dan memperkuat waktu yang tersedia untuk latihan yang berbeda.

\section{Efektivitas}

Efektivitas adalah tingkat pemanfaatan sumber daya manusia(tenaga kerja, uang, inovasi, dan komponen yang tidak dimurnikan) yang diperluas sepenuhnya dengan maksud memperluas efek samping dari setiap unit dalam pemanfaatan aset.

\section{Kemandirian}

Kemerdekaan adalah tingkat seorang yang benar-benar mau melakukan kapasitas kerjanya yang ditunjukkan dengan tanggung jawab pekerjaan. Kebebasan juga merupakan tingkat di mana karyawan memiliki jaminan untuk bekerja dengan kantor dan kewajiban pekerja di tempat kerja.

\section{Kepuasan Kerja}

Wexley dan Yuki dalam Azhari \& Supriyatin, (2020) kepuasan kerja merupakan generalisasi sikap-sikap teerhadap pekerjaannya. Handoko dalam Azhari \& Supriyatin, (2020) berpendapat bahwa kepuasan kerja adalah keadaan emosional yang menyenangkan atau tidak menyenangkan dengan mana para karyawan memandang pekerjaan mereka. Purwana (Kaltsum et al., 2021) dalam Kepuasan kerja sebagai tanggapan emosional yang berbentuk kesenangan ketika keinginan tercapai, rekan kerja, promosi,dan gaji yang diinginkan sesuai dengan yang diharapkan.

\section{Indikator kepuasan kerja}

Indikator kepuasan kerja menurut Azhari \& Supriyatin, (2020) sebagai berikut :

1 Gaji

2 Promosi

3 Kompensasi selain kerja

4 Rekan kerja

5 Sifat pekerjaan, dan

6 Komunikasi 


\section{Disiplin kerja}

Waridin dalam Bachtiar arifudin husain, (2019) disiplin kerja adalah merupakan suatu bentuk ketaatan terhadap aturan, baik tertulis maupun tidak tertulis yang telah ditetapkan. Kedisiplinan dapat diartikan bilamana karyawan selalu datang dan pulang tepat pada waktunya, mengerjakan semua pekerjaannya dengan baik, mematuhi semua peraturan perusahaan dan norma sosial yang berlaku.

\section{Indikator disiplin kerja}

Menurut Sekartini dalam (Candana, 2021) menjelaskan bahwa disiplin kerja memiliki beberapa bagian yang dapat dijadikan sebagai petunjuk yang mempengaruhi derajat disiplin pekerja dalam suatu organisasi,sebagai berikut:

\section{$1 \quad$ Kehadiran.}

Hal ini adalah penanda penting untuk mengukur disiplin, dan sebagian besar karyawan yang memiliki disiplin kerja rendah biasanya datang lebih lambat dari yang diharapkan atau pulang lebih awal.

\section{$2 \quad$ Ketaatan terhadap peraturan kerja.}

Karyawan yang patuh pada peraturan kerja tidak akan mengabaikan metode kerja dan akan secara konsisten mematuhi aturan kerja yang ditetapkan oleh perusahaan.

\section{$3 \quad$ Ketaatan Pada Standar Kerja.}

Hal ini terlihat dari besarnya kewajiban pekerja terhadap usaha-usaha yang diberikan kepadanya.

\section{$4 \quad$ Tingkat Kewaspadaan Tinggi.}

Karyawan yang memiliki kewaspadaan tinggi akan secara konsisten berhatihati, memastikan dan menyeluruh dalam pekerjaan mereka dan secara konsisten menggunakan hal-hal secara efektif dan efisien.

\section{Bekerja Etis.}

Beberapa pekerja mungkin berpartisipasi dalam perilaku yang tidak pantas terhadap klien atau berpartisipasi dalam perilaku yang tidak pantas. Ini adalah jenis kegiatan disiplin, sehingga mengisi sebagai jenis disiplin kerja.

\section{Etos kerja}




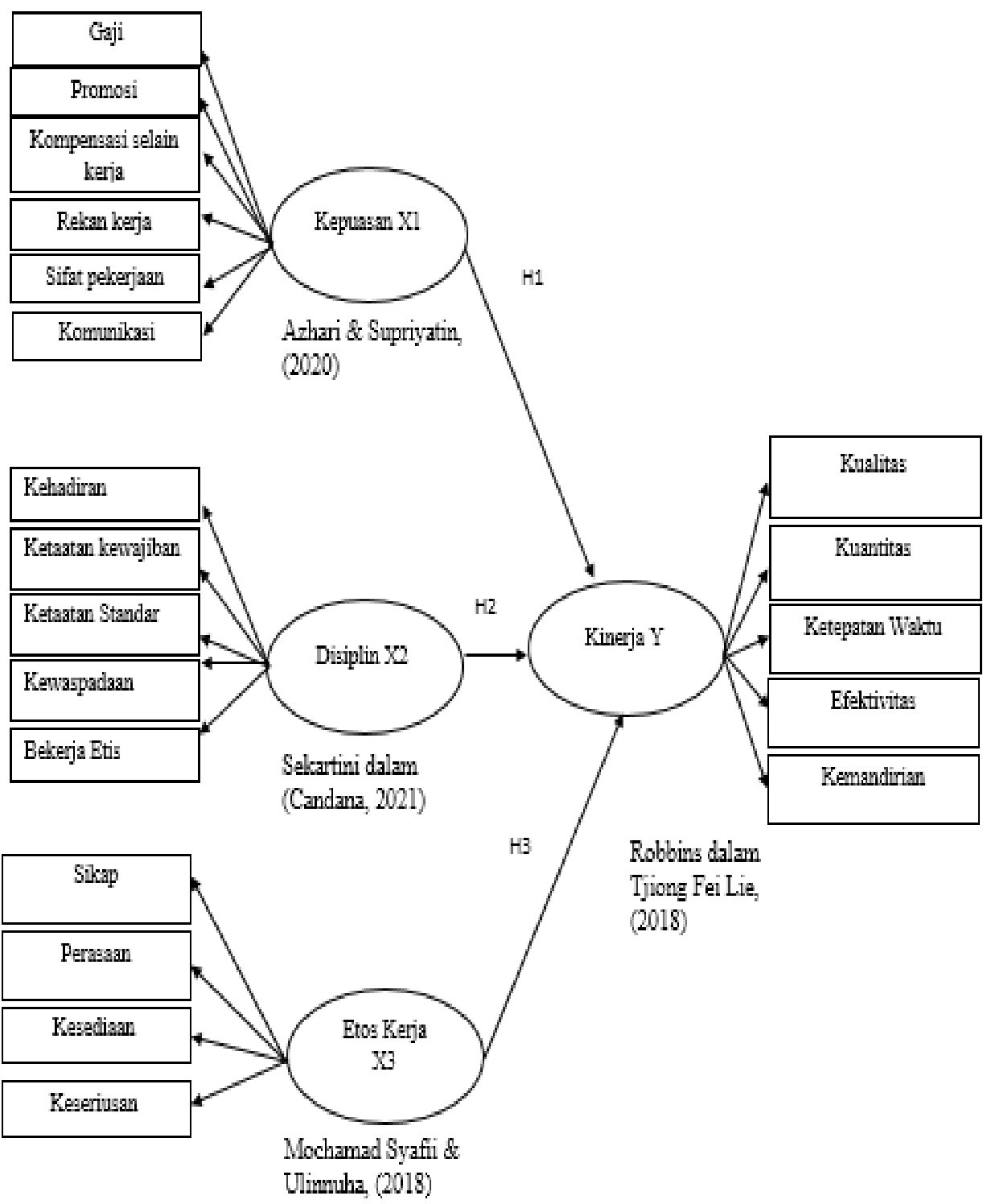

Etos kerja adalah sekumpulan prilaku positif yang dibangun dalam keyakinan utama yang digabungkan dengan kewajiban mutlak terhadap pandangan dunia kerja yang integral. Menurutnya, jika seorang, organisasi, atau komunitas berpegang pada pandangan dunia kerja, menaruh perhatian, dan fokus pada pandangan dunia kerja, semua itu akan melahirkan sikap dan prilaku kerja yang jelas. Itulah yang menjadi etos kerja dan budaya kerja keras Etos Arsad dalam Candana, (2021).

\section{Indikator Etos kerja}

Adapun indikator didalam Etos kerja Mochamad Syafii \& Ulinnuha, (2018) yaitu:

1 Sikap karyawan;

2 Perasaan seorang karyawan;

3 Kesediaan karyawan dalam melaksanakan pekerjaannya; 
4 Keseriusan dalam bekerja.

\section{Hipotesis penelitian}

Hipotesis 1 : kepuasan kerja akan berpengaruh terhadap kinerja

Hipotesis 2 : disiplin kerja akan berpengaruh terhadap kinerja

Hipotesis 3 : etos kerja akan berpengaruh terhadap kinerja

\section{METODELOGI PENELITIAN}

Sugiyono (2016:4) jenis penelitian dapat diatur tergantung pada tujuan, dan tingkat kealamiahan objek yang di teliti berdasarkan pada motivasi di balik strategi, penelitian dapat dikelompokan menjadi eksplorasi esensial, eksplorasi terapan dan penelitian peningkatan lebih lanjut berdasarkan metode kealamiahan, metode penelitian dapat dikumpulkan ke dalam metode uji coba, tinjauan umum, dan penelitian naturalistik. Penelitian ini menggunakan metode kuantitatif, metode yang menekankan pada aspek pengukuran secara objektif terhadap penomena sosial.

Hal tersebut berdasarkan pada judul yang diteliti yaitu "Pengaruh kepuasan, disiplin kerja, dan etos kerja terhadap kinerja karyawan PT. Keihin ndonesia". Penulis ingin mengetahui apakah ada pengaruh kepuasan, disiplin kerja dan etos kerja terhadap kinerja karyawan.

\section{HASIL DAN PEMBAHSAN}

Hasil analisis deskriptif menggambarkan bahwa dari 70 orang responden pada penelitian ini, $81 \%$ pria dan $19 \%$ wanita. Rata-rata masa kerja karyawan berkisar 1-2 tahun dengan rata-rata usia 20-30 tahun sedangkan pendidikan terakhir mayoritas karyawan adalah sekolah menengah umum dan berstatus belum menikah

Tabel 1.1 Hasil Uji Reliabilitas

\begin{tabular}{|l|r|l|}
\hline Variabel & $\begin{array}{l}\text { N } \\
\text { item }\end{array}$ & $\begin{array}{l}\text { Nilia } \\
\text { Cronbach } \\
\text { Alpha }\end{array}$ \\
\hline $\begin{array}{l}\text { Kepuasan } \\
\text { Kerja }\end{array}$ & 8 & 0,855 \\
\hline Disiplin & 8 & 0,749 \\
\hline Etos Kerja & 8 & 0,774 \\
\hline Kinerja & 8 & 0,786 \\
\hline
\end{tabular}

Tabel 1.2 Hasil Uji Validitas

\begin{tabular}{|l|l|l|}
\hline Variabel & $\begin{array}{l}\text { Test } \\
\text { KMO }\end{array}$ & $\begin{array}{l}\text { Bartlet } \\
\text { t Test }\end{array}$ \\
\hline $\begin{array}{l}\text { Kepuasan } \\
\text { Kerja }\end{array}$ & 0.711 & 0.000 \\
\hline Disiplin & 0.755 & 0.000 \\
\hline
\end{tabular}




\begin{tabular}{|l|l|l|} 
Etos Kerja & 0.783 & 0.000 \\
\hline Kinerja & 0.767 & 0.000 \\
\hline
\end{tabular}

Tabel 1.3 Ringkasan Uji Hipotesis

\begin{tabular}{|l|l|l|l|}
\hline Kode & Uraian Hipotesis & $\begin{array}{l}\text { T } \\
\text { Value }\end{array}$ & Kesimpulan \\
\hline H1 & $\begin{array}{l}\text { Kepuasan Kerja berpengaruh } \\
\text { positif terhadap kinerja karyawan } \\
\text { PT. Keihin Indonesia }\end{array}$ & 5.195 & Diterima \\
\hline H2 & $\begin{array}{l}\text { Disiplin berpengaruh positif } \\
\text { terhadap kinerja karyawan Pt. } \\
\text { Keihin Indonesia }\end{array}$ & 2.106 & Diterima \\
\hline H3 & $\begin{array}{l}\text { Etos Kerja berpengaruh positif } \\
\text { terhadap kinerja karyawan PT. } \\
\text { Keihin Indonesia }\end{array}$ & 3.094 & Diterima \\
\hline
\end{tabular}

\section{PEMBAHASAN}

\section{Pengaruh Kepuasan Kerja (X1) Terhadap Kinerja Karyawan (Y)}

Berdasarkan uji yang telah dilakukan dari hasil pengujian pada uji t hitung sebesar $5.195>$ t tabel 1,998 dan nilai sig 0,000 < 0,05, sehingga dapat disimpulkan bahwa berpengaruh secara parsial dan signifikan antara kepuasan kerja terhadap kinerja karyawan.

\section{Pengaruh Disiplin (X2) Terhadap Kinerja Karyawan (Y)}

Berdasarkan uji yang telah dilakukan dari hasil pengujian pada uji t hitung sebesar $2.106>$ t tabel 1,998 dan nilai sig 0,039 < 0,05, sehingga dapat disimpulkan bahwa berpengaruh secara parsial dan signifikan antara disiplin terhadap kinerja karyawan

\section{Pengaruh Etos Kerja (X3) Terhadap Kinerja Karyawan (Y)}

Berdasarkan uji yang telah dilakukan dari hasil pengujian pada uji t hitung sebesar $3.094>\mathrm{t}$ tabel 1,998 dan nilai sig 0,003 < 0,05, sehingga dapat disimpulkan bahwa berpengaruh secara parsial dan signifikan antara Etos Kerja terhadap kinerja karyawan.

\section{Koefisien Determinasi Kepuasan Kerja, Disiplin, Etos Kerja Terhadap Kinerja}

Nilai R Square sebesar 0,610 atau 61\%. menunjukan besarnya sumbangan pengaruh kepuasan, disiplin, dan etos kerja terhadap kinerja karyawan. Sedangkan sisanya 39\% dipengaruhi oleh variabel lain yang tidak diteliti dalam penelitian ini. Koefisien kolerasi (R) menunjukkan kekuatan hubungan variabel kepuasan kerja, disiplin, dan etos kerja dengan kinerja karyawan.

\section{KESIMPULAN}


Berdasarkan pada hasil penelitian dan pembahasan maka penulis dapat menarik beberapa kesimpulan sebagai berikut:

1. Kepuasan kerja berpengaruh positif dan signifikan terhadap kinerja karyawan di PT. Keihin Indonesia, hal ini dilihat dari nilai $\mathrm{T}_{\text {hitung }}$ sebesar 5,195 lebih besar dari 1,668 $(5,195>1,668)$ dan nilai signifikansi sebesar 0,000 lebih kecil dari $0,05(0,000<0,05)$, dan koefisien regresi mempunyai nilai positif sebesar 0,411 .

2. Disiplin kerja berpengaruh positif dan signifikan terhadap kinerja karyawan di PT. Keihin Indonesia, hal ini dilihat dari nilai $\mathrm{T}_{\text {hitung }}$ sebesar 2,106 lebih besar dari 1,668 (2,106>1,668) dan nilai signifikansi sebesar 0,039 lebih kecil dari $0,05(0,039<0,05)$, serta koefisien regresi mempunyai nilai positif sebesar 0,143 .

3. Etos kerja berpengaruh positif dan signifikan terhadap kinerja karyawan di PT. Keihin Indonesia, hal ini dilihat dari nilai $\mathrm{T}_{\text {hitung }}$ sebesar 3,094 lebih besar dari 1,668 (3,094>1,668), dan nilai signifikansi sebesar 0,003 lebih kecil dari $0,05(0,003<0,05)$, serta koefisien regresi mempunyai nilai positif sebesar 0,310

\section{SARAN}

1 Peneliti selanjutnya dapat mengembangkan penelitian ini dengan menggunakan metode lain dalam meneliti pengaruh kepuasan kerja, disiplin kerja dan etos kerja terhadap kinerja karyawan, misalnya melalui wawancara mendalam terhadap responden, sehingga informasi yang diperoleh dapat lebih bervariasi dari pada angket yang jawabannya telah tersedia.

\section{DAFTAR PUSTAKA}

Akwani, A. (2021). PENGARUH ETOS KERJA, LINGKUNGAN KERJA DAN KOMITMEN ORGANISASI TERHADAP KINERJA PEGAWAI PT. SABA NDOMEDIKA SURABAYA. Jurnal lmu Dan Riset Manajemen, 10(4), 1-17.

Aqsariyanti, L., Sjahruddin, H., \& Razak, N. (2019). Pengaruh Etos Kerja dan klim Organisasi Terhadap Kinerja Karyawan. 1(1). https://doi.org/10.31219/osf.io/ue73v

Arda, M. (2017). Pengaruh Kepuasan Kerja Dan Disiplin Kerja Terhadap Kinerja Karyawan Pada Bank Rakyat ndonesia Cabang Putri Hijau Medan. Jurnal lmiah Manajemen \& Bisnis, 18(1), 45-60.

Astutik, M. (2016). Pengaruh Disiplin kerja dan BUdaya Organisasi Terhadap Kinerja pegawai sekretariat dewan perwakilan rakyat daerah kabupaten jombang. JBMP (Jurnal Bisnis, Manajemen Dan Perbankan), 2(2), 121. https://doi.org/10.21070/jbmp.v2i2.1098

Azhari, R., \& Supriyatin. (2020). Engaruh Kepuasan Kerja, Disiplin Kerja, Dan Motivasi Kerjaterhadap Kinerja Karyawanpt Pos Indonesia Surabaya. Jurnal Ilmu Dan Riset Manajemen, 9(6), 1-25.

Bachtiar arifudin husain. (2019). Pengaruh Disiplin Terhadap Kinerja Karyawan Pada Pt. Bank Danamon, Tbk. Cabang Bandung. Jurnal Ekonomi Efektif, 1(4), 276. https://doi.org/10.32493/jee.v1i4.10709

Butarbutar, M., Efendi, Simatupang, S., \& Sianturi, M. (2021). Maker: Jurnal 
Manajemen PENGARUH ETOS KERJA TERHADAP KINERJA KARYAWAN PADA YAYASAN SARI ASIH NUSANTARA PEMATANGSIANTAR. 7(May), 116-124.

Candana, D. M. (2021). Determinasi Prestasi Kerja Dan Kepuasan Kerja: Etos Kerja Dan Disiplin Kerja (Suatu Kajian Studi Literatur Manajemen Sumberdaya Manusia). Jurnal Ilmu Manajemen Terapan, 2(4), 544-561. https://doi.org/10.31933/jimt.v2i4.471

Ichsan, R. N., Surianta, E., \& Nasution, L. (2020). Pengaruh Disiplin Kerja Terhadap Kinerja Pegawai Negeri Sipil (Pns) Di Lingkungan Ajudan Jenderal Daerah Militer (Ajendam) - I Bukitbarisan Medan. Jurnal Darma Agung, 28(2), 187. https://doi.org/10.46930/ojsuda.v28i2.625

Kaltsum, N. rahmah dani, Husniati, R., \& Fadlilah, A. min. (2021). PENGARUH KEPUASAN KERJA DAN DISIPLIN KERJA TERHADAP KINERJA PEGAWAI DI PUSAT PENYULUHAN PERTANIAN KEMENTERIAN PERTANIAN. Business Management, Economic, and Accounting National Seminar Volume, 2, 781-791.

Mochamad Syafii, \& Ulinnuha, M. (2018). Pengaruh Etos Kerja Dan Budaya Organisasi Terhadap Kinerja PT. Ananda Jataka Bayu Sejahtera (AJBS) Dikota Gresik. Jurnal Fakultas Ekonomi, 07(01), 61-69.

Muslimat, A., \& Wahid, H. A. (2021). Pengaruh Disiplin Kerja Terhadap Kinerja Karyawan Pada PT. Pos Indonesia Kantor Cipondoh. JENIUS (Jurnal Ilmiah $\begin{array}{lllll}\text { Manajemen Sumber } & \text { Daya }\end{array}$ https://doi.org/10.32493/jjsdm.v4i2.9080

Nurjaya, N., Sunarsi, D., Effendy, A. A., Teriyan, A., \& Gunartin, G. (2021). Pengaruh Etos Kerja Dan Disiplin Kerja Terhadap Kinerja Pegawai Pada Dinas Kehutanan Dan Perkebunan Kota Bogor. JENIUS (Jurnal Ilmiah Manajemen Sumber Daya Manusia), 4(2), 172. https://doi.org/10.32493/jjsdm.v4i2.9086

Partika, P. D., Ismanto, B., \& Rina, L. (2020). Pengaruh Stres Kerja, Disiplin Kerja Dan Kepuasan Kerja Terhadap Kinerja Karyawan Ekowisata Taman Air Tlatar Boyolali. Jurnal Benefita, 5(2), 308-323.

Salsabila, R., \& Anitra, V. (2021). Pengaruh Etos Kerja Terhadap Kinerja Karyawan: Studi Pada Tenaga Kependidikan Universitas Muhammadiyah Kalimantan Timur. 2(2), 1477-1486.

Sari, O. R. (2018). Pengaruh Kepuasan Dan Motivasi Kerja Terhadap Kinerja Karyawan Dengan Organizational Citizenship Behavior (Ocb) Sebagai Variabel Intervening. Management Analysis Journal, 4(1), 28-35. https://doi.org/10.15294/maj.v4i1.7221

Sugiyono. (2016). METODE PENELITIAN KUANTITATIF, KUALITATIF, DAN R\&D (Cetakan ke). ALFABETA, CV. www.cvalfabeta.com

Syafrina, N. (2018). Faktor-Faktor Yang Mempengaruhi Kepuasan Kerja Karyawan Pada Pt. Aspacindo Kedaton Motor Kandis Kabupaten Siak. Jurnal Benefita, 3(3), 455. https://doi.org/10.22216/jbe.v3i3.3004

Tjiong Fei Lie, H. S. (2018). Pengaruh Kepuasan Kerja Terhadap Kinerja Karyawan Melalui Motivasi Kerja pada CV. Union Event Planner. Agora, 6(1), 1-6.

Umar, H. D. said, \& Rokhyadi, A. permana. (2020). ANALISIS FAKTOR-FAKTOR YANG MEMPENGARUHI KEDISIPLINAN KERJA PADA KARYAWAN ANALYSIS OF FACTORS THAT AFFECT WORK DISCIPLINE IN EMPLOYEES OF PT 
E-ISSN : 2599-3410 | P-ISSN : 2614-3259

DOI : https://doi.org/10.36778/jesya.v5i1.563

SKATINDO IN. 8(1), 70-78. 